Polish Biographical Studies 2020, NR 8 ISNN 2353-9291

DOI $10.15804 / p b s .2020 .07$

Nina PIELACIŃSKA

ORCID 0000-0002-4839-9335

\title{
The Emigration Biography OF STANISLAW LIS-KOZLOWSKI in Selected Texts by Representatives of the Polish Community in Argentina
}

Słowa kluczowe: Stanisław Lis-Kozłowski (1907-1995), dzieje polskiej kultury, emigracja, Polonia argentyńska

Keywords: Stanisław Lis-Kozłowski (1907-1995), history of Polish culture, emigration, Polish community in Argentina

\begin{abstract}
The aim of this article is to present the life and achievements of Stanislaw Lis-Kozlowski in exile, with particular emphasis on his contribution to Polish culture. The analysis is based on source texts, Argentinean polonica, prose memoirs of emigrants in Argentina, Polish emigrant journals, as well as other publications related to the life and activity of Lis-Kozlowski. An important source of information for this biography was the Argentine collection of the Library of the Poznan Society of the Friends of Science (in Polish: PTPN), the archival collection held in the Ignacy Domeyko Polish Library in Buenos Aires (Biblioteca Polaca Ignacio Domeyko) and the archives of the Franciscan Monastery in Martin Coronado in Argentina. The study required the use of appropriate research methods, such as biographical interpretive method and narrative analysis.
\end{abstract}


7 he history of the Polish community in Argentina is approached within the $\perp$ context of political and social processes usually concerning emigration, a description of its stages, and how migrants function in new homes ${ }^{1}$. However, to this day, little research has been done into the lives, activities, and works of Poles, emphasizing their achievements and activities abroad. Apart from the writer Witold Gombrowicz, many Polish activists, writers, artists, historians, geographers, doctors, or engineers are almost unknown in Poland today. Individual fates are lost in general historical and sociological studies on Polish emigration. Therefore, it is important to undertake biographical research on the Polish community in Argentina and save from oblivion the legacy of many outstanding Poles scattered worldwide.

The article is an outcome of broader research that aim to present Polish activists' life and work in Argentina. The subject of interest in this text is the story of Stanislaw Lis Kozlowski, a Polish emigrant in Argentina, a distinguished military man, diplomat, social activist, popularizer of history and culture. In commonly available sources, we can find only short biographical notes, mainly related to this officer's military merits ${ }^{2}$. The biography of Lis-Kozlowski ends in 1948 when he emigrated to Argentina, where he spent over 47 years. His exile activity, contribution to the promotion of Polish history and culture, and work for national heritage are invaluable. To reconstruct the biography of Stanislaw Lis-Kozlowski, I use source texts, Argentinean Polonica, prose memoirs of emigrants in Argentina, Polish migrant journals, and other publications related to his life and work.

An essential source of information for this biography was the Argentine collection of the Library of the Poznan Society of the Friends of Science (in

1 The history of the Polish community in Argentina has been written about, among others by: W. Wójcik, Polacy w Brazylii, Argentynie i Urugwaju w XIX i XX wieku, „Dzieje Najnowsze" 1972, vol. 2, pp. 87-88; M. Paradowska, Polacy w Ameryce Południowej, Wrocław 1977, pp. 45-46; K. Smolana, Polonia w Argentynie. Rys historyczny, [in:] Dzieje Polonii w Ameryce Łacińskiej, ed. M. Kula, Wrocław 1983, pp. 215-218; J. Mazurek, Kraj a emigracja. Ruch ludowy wobec wychodźstwa chłopskiego do krajów Ameryki Łacińskiej (do 1939 roku), Warszawa 2006, pp. 83-84.

2 B. Polak, Kawalerowie Virtuti Militari 1792-1945. Konspiracja 1939-1945, T. 5/I., Koszalin 1999, p. 66; E. S. Urbański, Sylwetki polskie w Ameryce Eacińskiej w XIX-XX wieku, vol. 1, Stevens Point 1991, pp. 223-224; B. Andrzejewski, Stanisław Lis-Kozłowski (1907-1995), „Lingua ac Communitas” 1996, vol. 6, pp. 105-107. 
Polish: PTPN) ${ }^{3}$, whose donor was a long-time Polish emigrant, Stanislaw Lis Kozlowski. This collection contains primarily Argentinean Polonica and source materials related to the Polish community's activities in Argentina. The precious sources used for research into the biographical history of the Polish community in Argentina also include the archival collection held in the Ignacy Domeyko Polish Library (Biblioteca Polaca Ignacio Domeyko, from now on BPID) and the archives of the Franciscan Monastery in Martin Coronado, which contains materials produced by various institutions and individuals working in exile. A significant collection is the private archive of Fr. Herkulan Wróbel, a long-time employee and rector of the Catholic Mission, including the series: "Poles in Argentina", containing documents of numerous Polish organizations and the legacy of Poles living in this country ${ }^{4}$. The BPID, in collaboration with the KARTA Center Foundation, established in 2012 the Digital Archive of Local Tradition in Buenos Aires, thanks to which it was possible to digitize 3900 photographs and record 55 biographical accounts of Poles and people of Polish origin in Argentina. The resulting collection is presented on the website of the Ignacy Domeyko Library ${ }^{5}$.

\section{Childhood and Youth}

Stanislaw Tadeusz Platon Lis z Kozlow Kozlowski (born 22.02.1907 in Warsaw) comes from a family of nobility and intelligentsia ${ }^{6}$. He was the son of

3 More on the collection in the article: I. Pempera, Kolekcja argentyńska w Bibliotece Poznańskiego Towarzystwa Przyjaciół Nauk, „Biblioteka” 2010, no. 14(23), pp. 261-268.

4 The content of the archive catalogs can be found on the website of Polonia Digital Library (PBC): http://www.pbc.uw.edu.pl/view/divisions/Archiwum=5FCoronado.html (11.10.2020).

${ }^{5}$ In addition, through cooperation with the Supreme Directorate of State Archives, collections are systematized and developed. Collection inventories can be found on the website https://szukajwarchiwach.pl/713\#tabInformacje (11.10.2020).

6 The surname comes from the Kozlow village in the Jędrzejów region, and the family coat of arms is one of the oldest in Poland. Some of the more important members of the Kozlowski family include Mikołaj of Kozłów (d.1433), professor of theology and rector of the Jagiellonian University, to whom Stanisław Lis-Kozłowski donated a commemorative plaque in the church of the Cistercian abbey in Jędrzejów. More about the 
Maria Barbara (née Hildebrant) and Wladysław Mieczyslaw Kozlowski ${ }^{7}$ (1858-1935), philosopher, sociologist, botanist; active in the field of higher education after Poland regained independence. W.M. Kozlowski worked at universities in Krakow, Geneva, Paris, and Poznan, where he held the position of deputy professor of the Chair of Theory and Methodology of Natural Sciences and Humanities at the Faculty of Philosophy of the University of Poznan. He was also the founder and first president of the Poznan Philosophical Society, and a member of the Philosophical Commission of the Poznan Society of the Friends of Science. In 1931, he moved with his family to the villa "Hypatia" in Konstancin, which he designed and named after Hypatia of Alexandria (355-415), considered to be the first woman philosopher.

Stanislaw received a thorough education at the Mikolaj Rej Private Male Gymnasium of the Evangelical-Augsburg Church in Warsaw. From the very beginning, he was active in the school's 8th Warsaw Scouting Troop named after Kazimierz Pułaski, and from 1919, in the Poznan scouting. In 1920, he served as a volunteer in the company of the General District Command in Poznan. In 1927, he passed the Matura exam in Gotthilf Berger Gymnasium in Poznan, and in the same year, he started studies at the Poznan University. Next, he studied at Warsaw and Prague Polytechnic, and also in France, getting the diploma of chemical engineer in Ernest Denis Institute in Paris ${ }^{8}$. During his studies, especially in Prague, he was active in many Polish, Slavic, and Czechoslovak-Polish associations. He also worked at Skoda plants in Prague and Pilsen ${ }^{9}$. In 1934-1935, he was adept at the Artillery Reserve Cadet School

history of Kozlow and the Kozlowski family: Historia wsi Kozłów http://www.kozlow.pl/ art,175, historia-wsi-kozlow\&kalendarz=2017-08.html (11.10.2020).

${ }^{7}$ More about Wladysław Kozlowski has been written, among others, by Z. E. Roskal, Kozłowski Władysław Mieczysław, [in:] Encyklopedia filozofii polskiej, vol. I, ed. A. Maryniarczyk, Lublin 2011, pp. 744-746; B. J. Gawecki, Władysław Mieczysław Kozłowski (1858-1935), Wrocław 1961. Więcej na temat opublikowanych tekstów filozofa: S. Lis-Kozłowski, Bibliography of Władysław Mieczysław Kozłowski, „Lingua ac Communitas” 1995, no. 4, pp. 65-107.

8 Z. Judycki, Mazowszanie w świecie, cz. V, „Niepodległość i Pamięć” 2016, no. 4(56), p. 290.

${ }^{9}$ K. Dopierała, Encyklopedia polskiej emigracji i Polonii: K-O, vol. 3, Toruń 2004, pp. 167-168. 
in Wlodzimierz Wolynski ${ }^{10}$. Then he was allocated to the 1st Division of Horse Artillery named after Jozef Bem in Warsaw. Next, he worked in the chemical industry, quickly rising to deputy technical director position in the "Boruta" chemical industry group. During the Second World War, after the Germans took over "Boruta" factories, he volunteered for the army (reserve officer) in Lutsk. He fought in Dubno, Hrubieszów and Polesie groups. After the battle of Kock, he got to Warsaw, where he joined the conspiracy. He conducted classes in Czech at the clandestine Slavonic Studies of the Faculty of Humanities at the University of Warsaw. He was also a member of the Commission for Polish-Czech Affairs, established in 1942 ${ }^{11}$. Under the pseudonym "Mściwój", he then published an article in the secret occupation press titled "The Idea of the Federation of Slavs in Polish and Czech Philosophical Thought ${ }^{12}$. He took part in the Warsaw Uprising as an aide-de-camp to a deputy commander of the "Bartkiewicz" grouping. Since the middle of August, due to the constant demand for high-energy materials for grenades production, he moved to the Independent Division of Unexploded Ordnance Disposal ${ }^{13}$, which dealt with the disarmament production of explosives. At the time, the division was headed by Franciszek Niepokólczycki "Teodor", whose merits were reminded to Poles by Lis-Kozlowski when he wrote an article the commander in the Parisian "Zeszyty Historyczne" in $1976^{14}$. It is worth mentioning that Lis-Kozlowski was decorated with the Silver Cross of the Virtuti Militari War Order (No. 13870) in 1944 for his outstanding merits and valor during his service in the Home Army, and at the same time promoted to the rank of captain ${ }^{15}$.

10 Vide: Rocznik Szkoły Podchorążych Rezerwy Artylerii, R.1934/1935, Biblioteka Uniwersytecka w Poznaniu: https://www.wbc.poznan.pl/dlibra/publication/109615/edition/120578/content?ref=struct (15.10.2020).

11 Vide: P. Matusak, Idea federacji Europy Środkowo-Wschodniej w planach polskiego podziemia, [in:] Państwa narodowe Europy Środkowo-Wschodniej w XX wieku, ed. W. Balcerak, Łowicz-Warszawa 2000, p. 215.

12 S. Lis-Kozłowski, Idea federacji Słowian w myśli filozoficznej polskiej i czeskiej, „Wojsko i wychowanie" 1992, no. 4, pp. 45-49.

13 S. Lis-Kozłowski, Recuerdos de Guerra, Buenos Aires 1964.

14 S. Lis-Kozłowski, Teodor (excerpt from „Fragmentów wspomnień z okupacji i powstania”), „Zeszyty historyczne” 1976, vol. 268, no. 38, pp. 180-192.

15 B. Polak, Kawalerowie Virtuti Militari..., op.cit., p. 66. 
After the fall of the uprising, he was the Polish liaison officer to the French occupation authorities in Germany. Then, as a result of the Polish Army's demobilization, he emigrated from Great Britain to Argentina, from where he never returned to his homeland.

\section{Stanislaw Lis Kozlowski in Argentina}

One of the people who has particularly positive memories of the Polish emigrant is Józefa Radzyminska ${ }^{16}$. In her book Orzet Biaty nad Rio de la Plata, the author describes the engineer, emphasizing his merits as a defender of his homeland and a soldier of the Home Army: the "great-grandson of Wawrzyniec, an officer in the Napoleonic army, son of Wladyslaw, a philosopher and historian, former lecturer at the University of Warsaw, took part in the September campaign as an officer in the 1st Division of Horse Artillery, fought in the Battle of Kock. When on October 6, 1939, the last fighting unit of the regular Polish army, the so-called Kleeberg Group, ceased to exist and its soldiers were taken prisoner, Kozlowski managed to escape. He reached Warsaw and fought in the conspiracy; he fought in the August Uprising in the "Bartkiewicz" grouping and distinguished himself by capturing the Main Post Office on Napoleon Square"17. The information contained in the book published in 1971 also indicates that the collected data comes from the author's private conversations and correspondence with Lis-Kozlowski. J. Radzyminska returned to Poland in 1962, while Lis-Kozlowski's war memoirs were published in Buenos Aires only in 1964. It is known, however, that they were in touch for many years after Radzyminska's return to Poland, as evidenced by her recollection of their correspondence. "[...] Kozlowski sent me extensive letters with information about the life of the Polish community in Argentina, and in January 1972 he came to Warsaw, and we met for a nice chat about old times. He told me a lot about his untiring work both in Polonia and in numerous Argentinean historical societies (Instituto de Ciencias Genealógicas, Sociedad Argentina de Estudios Franceses), about the Argentinean school in Quilmes, which thanks

16 Vide: N. Pielacińska, A. Seniów, Argentyna w prozie wspomnieniowej Józefy Radzymińskiej. Perspektywa językowo-kulturowa, Szczecin 2020.

17 J. Radzymińska, Biały Orzeł nad Rio de la Plata, Warszawa 1971, p. 170. 
to his efforts was named after Tadeusz Kościuszko. [...] He was last in Warsaw in 1991 and we saw each other at a meeting of Warsaw insurgents from the "Bartkiewicz" grouping"18.

The writer greatly appreciated the activist's contribution to the popularization of Polish science, history, and culture abroad. Stanislaw Lis-Kozlowski was the founder and president of the Society of History Enthusiasts, whose beginning, according to various sources, dates back to $1954^{19}$ or $1957^{20}$. The information (1955), confirmed in Lis-Kozlowski's publications, is indicated only by the emigrant J. Radzyminska ${ }^{21}$. The Society was particularly interested in collecting Polonica and publishing texts concerning the history of the homeland and people connected with it. As a part of the Society's activity Lis-Kozlowski published i.a. Zbiory krzemienieckie ${ }^{22}$, Orty legionowe ${ }^{23}$, Articles on Tadeusz Kosciuszko, including a translation into Spanish of his father Wladyslaw Kozlowski's book Washington and Kosciuszko ${ }^{24}$. He added numerous comments and his article, introducing Argentinians to the profile of the eminent Pole. In other Spanish-language text Poznan y Poznañ: su significado en la historia de Polonia $y$ de las demas naciones eslavas ${ }^{25}$, he wrote about the role of that city in the history of Poland. Lis-Kozlowski made an invaluable contribution in conveying the knowledge about World War II experiences to Argentines (e.g. in the text Recuerdos de guerra from 1964) ${ }^{26}$. The fact that the Pole was a recognized historian in Argentine scholarly circles is evidenced by the inclusion of a biographical note in the book Historians of Argentina and America (Historia-

18 J. Radzymińska, Dedykacje, Warszawa 2000, p. 161.

${ }^{19}$ E. S. Urbański, Sylwetki polskie..., op.cit., p. 223.

20 B. Andrzejewski, Stanisław..., op.cit., p. 106.

${ }_{21}$ J. Radzymińska, Dedykacje..., op.cit., p. 161.

${ }^{22}$ S. Lis-Kozłowski, Zbiory krzemienieckie, „Kultura” 1972, no. 7/298-8/299, pp. 219-222.

${ }^{23}$ S. Lis-Kozłowski, Orty legionowe, „Kurier Polski” 1966. In the article the author discusses types and models of legion badges.

${ }^{24}$ S. Lis-Kozłowski, Testament Duchowy Kościuszki, Buenos Aires 1965; S. Lis-Kozłowski, Washington y Kosciuszko, El significado de Kosciuszko en la libertad de America, Buenos Aires 1962.

${ }^{25}$ S. Lis-Kozłowski, Poznan y Poznania: su significado en la historia de Polonia y de las demas naciones eslavas, "Historia" 1957, no. 7, p. 8.

${ }^{26}$ S. Lis-Kozłowski, Recuerdos de Guerra..., op.cit. 
dores Argentinos y Americanos) ${ }^{27}$. It was emphasized there that Lis-Kozlowski is an authority on heraldry, an active participant in international meetings, congresses, and events related to this field, a member of numerous associations and genealogical societies, including a member of the commission approving the coats of arms of provinces and cities in Buenos Aires.

However, the most important was the contribution and commitment of Lis-Kozlowski - the president of the Society of History Enthusiasts - in bringing the so-called Wawel treasures located in Canada. According to J. Radzymińska ${ }^{28}$, this issue played an important role in shaping the emigrants' opinions about Polish reality. According to the author, the main problem was the fact that the information sent from the country reached Argentina in an altered, often abridged version: "The echoes of the momentous changes after October 1956 often came to us distorted by the emigrant press, we were still cut off from true and reliable information, disoriented, after all, some glaring and essential truths were striking, the emigrant government defended the fallen entrenchments; when this government began to proclaim slogans, monstrous in their audacity, in the name of which it was better if the Wawel Treasures perished than that was returned to the People's Republic of Poland, public opinion became indignant. The treasures, bequeathed to the Polish nation in the royal wills, were its property and had to return to it" ${ }^{29}$.

As M. Kijewska-Trembecka points out ${ }^{30}$, the Polish government-in-exile in London did everything possible to prevent the treasures from returning to Poland for fear that the Soviets might take them to the Soviet Union. The communist government in Warsaw, on the other hand, made every effort to ensure that the royal possessions were brought back to Poland. However, it is worth mentioning that the treasures returning to the homeland were provided with a special clause, under which they became the property of the Pol-

27 V. O. Cutolo, Historiadores Argentinos y Americanos (1963-1965), Buenos Aires 1966, p. 198.

28 J. Radzymińska, Biały Orzeł..., op.cit, p. 170.

${ }^{29}$ Ibidem, p. 171.

${ }^{30}$ M. Kijewska-Trembecka, Losy Skarbów Wawelskich w Kanadzie, „Studia Migracyjne - Przegląd Polonijny" 2017, vol. 1(163), pp. 381-38. 
ish nation and not the government ${ }^{31}$. This provision was supposed to protect them from a possible takeover by Moscow.

Lis-Kozlowski, like Radzyminska, fully supported bringing the royal possessions to Poland. Accordingly, in addition to articles in the Polonia press ${ }^{32}$, he compiled, printed, and sent to emigration associations worldwide a brochure he had written entitled Skarby Wawelskie. Czy społeczność na emigracji ma możliwość przyczynić się do ich uratowania (Buenos Aires 1958) ${ }^{33}$. The author of the publication indicates that its purpose was "by once again recalling the sad facts, to alert the Polish public residing outside the country and to contribute in even a modest way to the cause of saving our National Relics from destruction or loss"34. As J. Radzymińska recalls ${ }^{35}$, it was a luxurious edition for emigration conditions, enriched with photographs of tapestries and royal treasures.

Beside the photographs, two items at the beginning and end of the brochure draw reader's attention. The first one is a copyright note by Lis-Kozlowski. It allows us to better understand the purpose and social value of the publication, as well as to appreciate the patriotic attitude of the author: "The author does not reserve any rights. On the contrary, he invites all those who care about the fate of our national treasures to reprint in whole or in part, in the original or in translation, to quote and use in any way they see appropriate the data collected in this brochure" ${ }^{\prime 36}$.

31 J. G. Castel, Polish Art Treasures in Canada - 1940-1960: A Case History, paper delivered at the sixty-eight Annual Meeting of the American Society of International Law, Washington, April 25-27, 1974, vide: M. Kijewska-Trembecka, Losy Skarbów..., p. 388.

32 S. Lis-Kozłowski, Zbrodnia wobec cywilizacji, "Kuryer Polski” 27 X 1958, no. 253, p. 4. Biblioteka Jagiellońska, 419881 V.

33 S. Lis-Kozłowski, Skarby Wawelskie. Czy społeczność emigracyjna ma możność przyczynić się do ich uratowania, Buenos Aires 1958.

34 S. Lis-Kozłowski, Skarby Wawelskie..., op.cit., p. 25.

35 J. Radzymińska, Dedykacje..., op.cit., p. 160.

36 S. Lis-Kozłowski, Skarby Wawelskie..., op.cit., p. 2. 


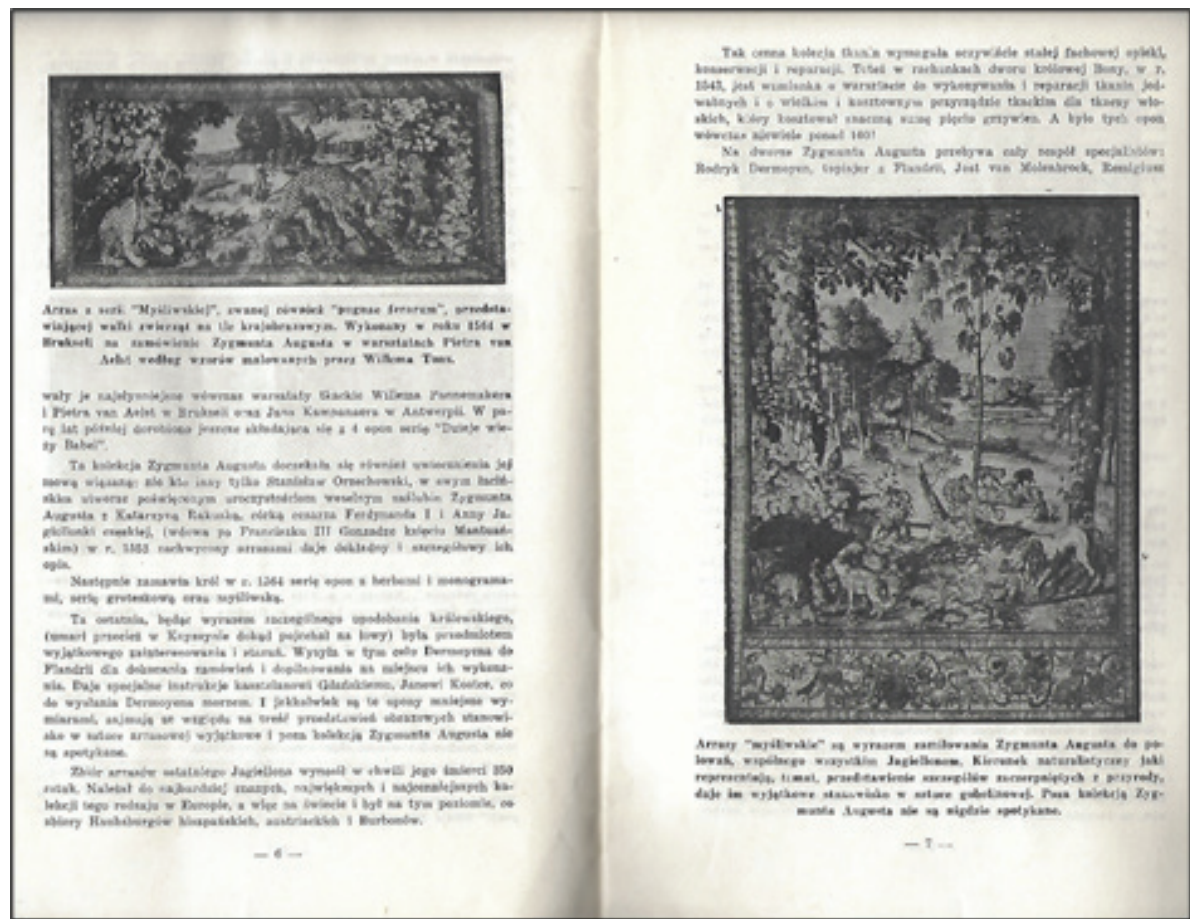

Fig.1. Photos of the Jagiellonian tapestries in the publication by S. Lis-Kozlowski (Source: Private archive of the author of this text)

The second element that draws attention is Cardinal Stefan Wyszyński's resposne to the letter from Lis-Kozlowski of November 20, 1958 ${ }^{37}$. The Bishop thanked the engineer for his correspondence and the enclosed works. He referred to the matter of the Wawel treasures, assuring the Polish activist that he fully supported his opinion and all actions connected with it. Lis-Kozlowski included the letter in the published brochure, being fully aware that thanks to the Church's authority, the interest in the subject of Wawel heritage would increase in the circles of Polonia.

It is true that the opinion of the Polish community in the world was divided, which is evidenced by the London journal "Orzeł Biały"38 publishing

37 Ibidem, p. 27.

38 Z czyjego ramienia?, „Orzeł Biały. Syrena: Polska walcząca o wolność” 4 II 1960, no. 5/918(615). 
critical view on the activities of the pianist, Witold Małcużyński, who contributed to the return of the first part of the treasure from Canada in 1959 ${ }^{39}$, as well as articles in the American press calling for action for the return of the treasures to Poland ${ }^{40}$. The Wawel tapestries returned to Krakow only two years later ${ }^{41}$, which was also contributed to by subsequent articles by Lis-Kozlowski, in which he did not allow Poles to forget about the precious keepsakes: "The Treasures of Wawel, or rather the matter of treasures - must not be forgotten and enveloped by silence ${ }^{42}$ ". Unfortunately, the Argentinean Polonia was also divided. An extraordinary Congress of Delegates of Polish Associations in Argentina was called (28.09.1958), and based on it, the opposing factions came to an agreement, and it was announced that: "with the greatest concern in passing the resolution, the representation of the Polish community of Argentina - its Assembly - appeals to all Polonia, in all territories, to pass similar resolutions and organize a joint action aimed at returning the Polish Nation its historical treasures" ${ }^{\prime 3}$. The quoted dispute is only one example of discord and division among Poles in Argentina.

Another element testifying to the internal disputes among the Argentinean Polonia were two competing magazines published in Buenos Aires: the organ of the Union of Poles, i.e., "Głos Polski" and "Kurier Polski" (1957-1976) ${ }^{44}$. The first was established in 1922, but the journal's editorial committee was not formed until twenty-seven years later ${ }^{45}$. A different vision from the right-wing

${ }^{39}$ More about the transfer of the Wawel treasures on the website of the Museum in Kraków: Rocznica powrotu Skarbów Wawelskich, https://wawel.krakow.pl/rocznica-powrotu-skarbow-wawelskich (10.10.2020).

40 W. Szul, Pomóżcie nam odzyskać Skarby Wawelskie z Kanady, „Kuryer Polski” 15 VIII 1958, no. 192, p. 3. Biblioteka Jagiellońska, 419881 V; W. Szul, Odezwa w sprawie Skarbów Wawelskich, „Kuryer Polski” 29 IX 1958, no. 229, p. 3. Biblioteka Jagiellońska, 419881 V.

41 Skarby Wawelskie wracaja do kraju, „Folha Polonesa. Przegląd Polski” 1961, no. 7, p. 23.

42 S. Lis-Kozłowski, Jeszcze - Skarby Wawelskie, „Kurier Polski” 15 X 1959, no. 114, p. 1.

43 J. Radzymińska, Biały Orzeł..., op.cit., p. 172.

44 M. Bryszewska, J. Gmitruk, J. Mazurek, Wstęp..., op.cit., p. 41.

45 Editorial Committee composed of: Zdzisław Gałaczyński, Wiktor Ostrowski, Jerzy Dittmar, Witold Horsztyński, ks. Szczepan Walkowski, Wacław Kozłowski, Seweryn Eustachiewicz, Stanisław Maria Gąssowski. Ibidem, pp. 39-40. 
"Głos Polski" was presented by the Polar company "Kurier Polski"46. Among the members of the mentioned company, we can distinguish Stanisław LisKozlowski. Therefore, it would seem that he was an opponent of the Union of Poles and a supporter of more left-wing activists. However, as we can see, according to the memoirs quoted by A. Omiljanowicz ${ }^{47}$, S. Lis-Kozlowski did not integrate with the Argentinean Polonia unless it was necessary, and he liked to act alone most of all. As the author of the book states in the subchapter with a significant title "Loner": "There are people who, acting alone, can do more than many social organizations. Engineer Stanislaw Lis-Kozlowski should be counted among them" ${ }^{48}$. The Pole, who appeared in Buenos Aires as part of the post-war emigration, at first kept a close eye on existing associations, arrangements, and acquaintances. He quickly found work, first at the chemical company E.J. Dupont de Nemour and then at Imperial Chemical Industry ${ }^{49}$. As soon as he became financially independent, he opened his own business and in 1955 settled near Buenos Aires in Mercedes (named by him Kozlowo), where he bred sport horses and, above all, devoted himself to scientific and journalistic activities ${ }^{50}$. In a way, isolating himself from the Polish community living in the capital, he described his compatriots in these words: "Most of the Poles here are occupied exclusively with work, with the struggle for existence, with mundane, everyday matters. A small group is engaged in the worst kind of politicking [...]. Remember that the Polish community here is by no means a loving family. There are various groups here, various arrangements, coteries, connections, groups that are often in conflict with each other, that hate each other, that fight against each other. And this is probably typical of all our emigrations" 51 .

A similar opinion about Poles in exile was held by Józefa Radzymińska, who in her memoirs also emphasized the internal divisions between Poles, even though she was actively involved in the social life of the Polish commu-

\footnotetext{
${ }^{46}$ Ibidem.

47 A. Omiljanowicz, Mozaika argentyńska, Warszawa 1984, pp. 321-325.

48 Ibidem, p. 321.

49 B. Andrzejewski, Stanisław..., op.cit., p. 106.

50 E. S. Urbański, Sylwetki polskie..., op.cit., p. 223.

51 A. Omiljanowicz, Mozaika..., op.cit. p. 324.
} 
nity $^{52}$. However, Zdzisław Bau, a post-war emigrant, had a different opinion on the Polish life in the country on the La Plata River, expressed in Thirty years later: Poles in Argentina ${ }^{53}$. According to the author, Polonia was distinguished by its extraordinary compliance and willingness to act for its homeland's benefit. However, he did not fail to criticize the then competitor of "Głos Polski", which was "Niezależny Kurier Polski w Argentynie" (1928-1947). As we can see, the Polish community's conflicts and mutual criticism translated even into memoirs of the emigrants. Therefore, the attitude adopted by S. Lis-Kozlowski is not surprising: "I am far from these people, I do not participate in the organized life of the local Polish community - I act alone. And if I did something good here, I did it for Poland. Working for Poland is my primary goal. [...] the most important and useful for the Polish community in Argentina will be: preventing too fast de-nationalization, so lectures, education, familiarizing young people with our past and cultural heritage" 54 .

On the one hand, the activist of the Polish community moves away from Buenosiren's social center. Still, at the same time, he does not spare criticism of the intelligentsia gathered around the "Polish House", especially the longtime president of the Union of Poles - Stanisław Pyzik. In addition to official publications in which the author directly comments on the activities of the representatives of the Polish community abroad, we can also find texts that express implicitly unflattering words about them. One example is published in 1967 in "Kurier Polski" the reader 70 years of Poles in Misiones ${ }^{55}$. The issue discussed in it raises the subject of documenting source texts and spreading knowledge about Polish culture. S. Lis-Kozlowski repeatedly emphasizes that the history of Polish emigration, apart from a short sketch in the book by J. Wlodek ${ }^{56}$, did not receive a good, diligent study, which would be based pri-

52 Vide: N. Pielacińska, A. Seniów, Józefa Radzymińska..., op.cit.

53 Z. Bau, Trzydzieści lat potem: Polacy w Argentynie, „Kultura” 1979, no. 4, p. 38.

54 A. Omiljanowicz, Mozaika..., op.cit., pp. 321, 324.

55 S. Lis-Kozłowski, 70 lat Polaków w Misiones. The lecture in "Ognisko Polskie" on 3 X 1967, „Kurier Polski” 1967, no. 524, pp. 3-29. The information about the speech of S. Lis-Kozlowski was also reported in the foreign press, including in neighboring Argentina - Brazil. (Polonia zagraniczna, 70-lecie Misiones, „Lud” 30 VIII 1967, no. 2928(35/67), Curitiba, Brazil.

56 J. Włodek, Argentyna i emigracja. Ze szczególnym uwzględnieniem emigracji polskiej, Warszawa 1923. 
marily on the critical use of literature, systematic search for scientific texts, and providing reliable sources ${ }^{57}$. During his lecture in Ognisko Polskie (1967), he made no mention of one of the most important publications on the history of the Argentinean diaspora - Stanislaw Pyzik's book Poles in Argentina ${ }^{58}$. This book was first published in 1966, which is exactly one year before the mentioned speech, and the publication of the text by Lis-Kozlowski in the "Kurier Polski". Moreover, the author of the paper adds that one should avoid "dilettante copying of unverified, often erroneous, and sometimes even fantastic news [...]. [What is missing is] a study by an objective historian of a true nature, with a scientific approach" ${ }^{59}$. Therefore, if Pyzik's text did not meet the mentioned expectations, and the only book about emigration is the position of J. Wlodek, it means that, according to the historian, the work of the president of the Union of Poles is unreliable, imitative, and worthless. S. Pyzik himself does not appreciate his countryman's activity, as evidenced by only one short sentence devoted to S. Lis-Kozlowski in a 280-page book, stating that the engineer writes historical works about Poznan, Kościuszko, and the world of Slavs ${ }^{60}$.

A critical approach to S.Pyzik's activity can also be confirmed by looking through the private collection of S. Lis-Kozlowski, made available by the Library of the Poznan Society of the Friends of Science ${ }^{61}$. Among the materials found, there are handwritten notes of the historian on, among others, Pyzik's articles. Lis-Kozlowski meticulously analyzed the texts of his compatriot, noting all the irregularities and inaccuracies. From the notes written in the margin, we can read that the historian accuses J. Pyzik, among others, that the published monograph about the history of emigration is a plagiarism of the books by J. Wlodek Argentina and emigration, Biografías Argentinas y Sudameri-

57 S. Lis-Kozłowski, 70 lat Polaków..., op.cit., p. 8.

58 The first text published by S. Pyzik: S. P. Pyzik, Los Polacos en la República Argentina 1812-1900, Buenos Aires 1944, then an expanded version from 1966 was published Los Polacos en la República Argentina y América del Sur desde el año 1812, Buenos Aires 1966 and it is these versions that S. Lis-Kozlowski should refer to. Polish edition: S. P. Pyzik, Polacy w Argentynie i innych krajach Ameryki Południowej, Warszawa 2004.

59 S. Lis-Kozłowski, 70 lat Polaków..., op.cit., p. 8.

60 S. Pyzik, Polacy w Argentynie..., op.cit., p. 253.

61 S. Lis-Kozłowski donated his collection of books to the PTPN Library in 1989. More about this issue: I. Pempera, Kolekcja argentyńska..., op.cit. pp. 261-268. 
canas by J. Yaben ${ }^{62}$ and obtained by deception materials by Gustaw Jasinski, whose father diligently collected them over the years.

Writing about the Polish community in Buenos Aires, we cannot omit the most famous Polish emigrant - Witold Gombrowicz. As we can read in the biography of the author of "Ferdydurke", Lis-Kozlowski took part in the philosophy courses conducted by the writer in Buenos Aire's salons, most often at the architect Krystyna Eichlerowa's house (at 958 Lambare Street) ${ }^{63}$. It was a figure particularly valued by the Polish historian, as evidenced by the article W Argentynie o Witoldzie Gombrowiczu published in 1970 in "Kurier Polski". It is a collection of reviews, opinions of critics, voices of writers, and journalists from Argentina on the figure and works of Witold Gombrowicz. All this was done so that the magazine readers, especially those who do not know the language and live abroad, could broaden their knowledge and become acquainted with the figure and works of the Pole. S. Lis-Kozlowski took this opportunity to criticize the Polish community again, stating: "As it seems, the small group of Polish intelligentsia in Argentina does not have anyone in its circle who could discuss, let alone write anything about Gombrowicz's literary production at a proper level"64. The author of the article himself calls Gombrowicz, the most outstanding writer of the Polish emigration, and the particular interest in his works is also evidenced by the mentioned Argentine collection, in which we can find books by Gombrowicz, including one with a dedication from the writer's wife, Rita (from 1973).

Stanislaw Lis-Kozlowski did not return to Poland and settled permanently in South America. In 1974-1980 he was a minister plenipotentiary of the Polish Government in Exile. He was an active member of numerous organizations, including the Instituto Cultural Argentino-Polaco, Instituto Argentino de Ciencias Genealógicas, Colegio Heráldico Argentino, Sociedad Científica Argentina, John Paul II Foundation Friends Society, Albert Einstein International Academy Fund (USA), Centro Argentino de Investigadores de Historia, Instituto Internacional de Genealogía y Heráldica, Polish Heraldic Society.

In 1991 he founded the Lis-Kozlowski Foundation and the Wladyslaw Mieczyslaw Kozlowski Thought and Life Institute (operating until 2006). The

62 J. R. Yaben, Biografías argentinas y sudamericanas, vol. 1, Buenos Aires 1938.

63 K. Suchanow, Gombrowicz. Ja, geniusz, vol. 2, Wołowiec 2017, p. 151.

64 S. Lis-Kozłowski, W Argentynie o Witoldzie Gombrowiczu, „Kurier Polski” 1970, p. 7. 
mission of the first one was to publish a scientific yearbook, to take care of the family collection and the family chapel of the Lis Kozlowski family at the Cistercian Church in Jędrzejów, as well as the W. M. Kozlowski Library at PTPN in Poznan. The latter foundation had the task of disseminating and promoting philosophical sciences, mainly Professor W.M. Kozlowski's ideas, and organizing valuable and numerous collections of books, manuscripts, and documents of the philosopher. In 1995, S. Lis-Kozlowski published for the fourth time a bibliography of texts by his father ${ }^{65}$. However, he did not manage to publish his list of Materiaty do bibliografii poloników argentynskich $1898-1982^{66}$, which also included a bibliography of over 200 of his works. Fortunately, as part of the Foundation's cooperation with the National Library, it was possible to publish this book in 1996. This item is a precious source of information since it includes both printed volumes and journals published in Polish and Spanish in Argentina during the 20th century ${ }^{67}$.

The merits for the homeland and the bravery during the World War II of S. Lis-Kozlowski was awarded twenty-four medals and sixteen distinctions. The most important ones include Silver Cross of the War Order Virtuti Militari, Cross of Valor, Officer's Cross of the Order of Polonia Restituta, Gold Cross of Merit with Swords, Home Army Cross, Warsaw Uprising Cross, Defense Medal (British distinction), War Medal 1939-1945 (British distinction), Croix du Combattant (French distinction) ${ }^{68}$.

65 S. Lis-Kozlowski, Bibliography of Władysław Mieczysław Kozłowski, „Lingua ac Communitas" 1995, no. 4, pp. 65-107.

66 S. Lis-Kozłowski, Materiały do bibliografii poloników argentyńskich. 1898-1982, Warszawa 1996.

67 A review of the book by this Polish activist should also be mentioned: M. A. Supruniuk, Polonica argentyńskie, "Archiwum Emigracji studia, szkice, dokumenty" 1998, vol. 1, pp. 225-227. On the pages of the journal the author of the review emphasized that it is difficult to check the completeness of the items included in the book because of the unknown material, poorly described in the available sources, but on the basis of several texts it was possible to notice significant shortcomings and errors, such as factual errors concerning the authors of translations, typos making it impossible to read a word, inconsistency in the application of the norms of bibliographic description, and incomplete information. The author concludes the review by stressing that one can only wish that other countries of Polish emigration receive similar (albeit equally incomplete) bibliographic lists.

68 B. Polak, Kawalerowie..., op.cit., p. 96. 
Stanislaw Lis-Kozlowski died in Buenos Aires on June 28, 1995 ${ }^{69}$. He rests in the Lis-Kozlowski family's tomb in the monastery church of the Cistercian abbey in Jędrzejów, where, as a descendant of the abbey founders, he also received a plaque with an inscription: "Stanislaw Tadeusz Platon hr. Lis z Kozlowa Kozlowski ${ }^{70}$. A symbolic gravestone of the Polish activist is also located at the Parish Cemetery in Skolimów.

\section{SUMMARY}

This article considers the emigration life and work of Stanislaw Lis-Kozlowski (1907-1995) - engineer, distinguished military man, Home Army officer, diplomat, social activist, and above all popularizer of Polish science, history and culture abroad. After the Second World War Lis-Kozlowski went to Argentina, where he spent 47 years of his life. He was a founder and president of the Society of History Enthusiasts in Buenos Aires, and a recognized authority in heraldry, genealogy and sfragistics. He actively participated in the life of the Polish community in Argentina, collecting Argentinean polonica, documenting its activities in exile. He published numerous texts on history and was involved in promoting the idea of bringing back to Poland the Wawel treasures which were taken from Poland at the beginning of World War II.

\section{BIBLIOGRAPHY}

\section{SOURCES}

Lis-Kozlowski S., Bibliography of Władysław Mieczysław Kozłowski, „Lingua ac Communitas"1995, no. 4, pp. 65-107.

Lis-Kozłowski S., 70 lat Polaków w Misiones. Odczyt wygłoszony w „Ognisku Polskim” dn. 3.9.67, „Kurier Polski” 1967, no. 524, pp. 3-29.

Lis-Kozłowski S., Idea federacji Słowian w myśli filozoficznej polskiej i czeskiej, „Wojsko i wychowanie" 1992, no. 4, pp. 45-49.

Lis-Kozłowski S., Jeszcze - Skarby Wawelskie, „Kurier Polski” 15 X 1959, no. 114.

69 Vide: Nekrologi warszawskie, http://www.nekrologi-baza.pl/zmarly/684608 (2.10. 2020).

70 According to Szymon Konarski in his book O heraldyce $i$ heraldycznym snobizmie Stanisław Lis-Kozłowski is an example of a "colorful snob, who for years has been collecting all possible titles, honors, and distinctions, and only at the age of 73 was able to legally confirm his title of nobility. The author of the book points out, however, that the value of this title is very relative. S. Konarski, O heraldyce i heraldycznym snobizmie, Warszawa 1992, p. 69. 
Lis-Kozłowski S., Materiały do bibliografii poloników argentyńskich. 1898-1982, Warszawa 1996.

Lis-Kozłowski S., Orty legionowe, Buenos Aires 1966.

Lis-Kozłowski S., Poznan y Poznania: su significado en la historia de Polonia y de las demas naciones eslavas, "Historia" 1957, no. 7.

Lis-Kozłowski S., Recuerdos de Guerra, Buenos Aires 1964.

Lis-Kozłowski S., Skarby Wawelskie. Czy społeczność emigracyjna ma możność przyczynić się do ich uratowania, Buenos Aires 1958.

Lis-Kozłowski S., Teodor (wyjątek z „Fragmentów wspomnień z okupacji i powstania”), „Zeszyty historyczne” 1976, vol. 268, no. 38.

Lis-Kozłowski S., Testament Duchowy Kościuszki, Buenos Aires 1965.

S.Lis-Kozłowski, Washington y Kosciuszko, El significado de Kosciuszko en la libertad de America, Buenos Aires 1962.

Lis-Kozłowski S., W Argentynie o Witoldzie Gombrowiczu, Buenos Aires 1970.

Lis-Kozłowski S., Zbiory krzemienieckie, „Kultura” 1972, no. 7/298-8/299.

Lis-Kozłowski S., Zbrodnia wobec cywilizacji, "Kuryer Polski” 27 X 1958, no. 253. Biblioteka Jagiellońska, 419881 V.

Skarby Wawelskie wracaja do kraju, „Folha Polonesa. Przegląd Polski” 1961, no. 7.

Szul W., Odezwa w sprawie Skarbów Wawelskich, „Kuryer Polski” 29 IX 1958, no. 229. Biblioteka Jagiellońska, 419881 V.

Szul W., Pomóżcie nam odzyskać Skarby Wawelskie z Kanady, „Kuryer Polski” 15 VIII 1958, no. 192, p. 3. Biblioteka Jagiellońska, 419881 V.

Z czyjego ramienia?, „Orzeł Biały. Syrena: Polska walcząca o wolność” 4 II 1960, no. 5/918(615).

70-lecie Misiones, „Lud” 30 VIII 1967, no. 2928 (35/67).

\section{STUDIES}

Andrzejewski B., Stanisław Lis-Kozłowski (1907-1995), „Lingua ac Communitas” 1996, vol. 6 .

Bau Z., Trzydzieści lat potem: Polacy w Argentynie, „Kultura” 1979, no. 4.

Bryszewska M., Gmitruk J., Mazurek J., Wstęp, [in:] Polonia argentyńska w piśmiennictwie polskim. Antologia, wstęp, wybór, Buenos Aires-Warszawa 2004.

Castel J. G., Polish Art Treasures in Canada - 1940-1960: A Case History, paper delivered at the sixty-eight Annual Meeting of the American Society of International Law, Washington, April 25-27, 1974.

Cutolo V. O., Historiadores Argentinos y Americanos (1963-1965), Buenos Aires 1966. Dopierała K., Encyklopedia polskiej emigracji i Polonii: K-O, vol. 3, Toruń 2004.

Gawecki B. J., Władysław Mieczysław Kozłowski (1858-1935), Wrocław 1961.

Judycki Z., Mazowszanie w świecie, cz. V, „Niepodległość i Pamięć” 2016, no. 4(56).

Kijewska-Trembecka M., Losy Skarbów Wawelskich w Kanadzie, „Studia Migracyjne Przegląd Polonijny" 2017, no. 1(163).

Konarski S., O heraldyce i heraldycznym snobizmie, Warszawa 1992. 
Matusak P., Idea federacji Europy Środkowo-Wschodniej w planach polskiego podziemia, [in:] Państwa narodowe Europy Środkowo-Wschodniej w XX wieku, ed. W. Balcerak, Łowicz-Warszawa 2000.

Mazurek J., Kraj a emigracja. Ruch ludowy wobec wychodźstwa chłopskiego do krajów Ameryki Łacińskiej (do 1939 roku), Warszawa 2006.

Omiljanowicz A., Mozaika argentyńska, Warszawa 1984.

Paradowska M., Polacy w Ameryce Południowej, Wrocław 1977.

Pempera I., Kolekcja argentyńska w Bibliotece Poznańskiego Towarzystwa Przyjaciót Nauk, „Biblioteka” 2010, no. 14(23).

Pielacińska N., Seniów A., Argentyna w prozie wspomnieniowej Józefy Radzymińskiej. Perspektywa językowo-kulturowa, Szczecin 2020.

Polak B., Kawalerowie Virtuti Militari 1792-1945. Konspiracja 1939-1945, vol. 5/I, Koszalin 1999.

Pyzik S. P., Polacy w Argentynie i innych krajach Ameryki Południowej, Warszawa 2004.

Radzymińska J., Biały Orzeł nad Rio de la Plata, Warszawa 1971.

Radzymińska J., Dedykacje, Warszawa 2000.

Roskal Z. E., Kozłowski Władystaw Mieczystaw, [in:] Encyklopedia filozofii polskiej, vol. I, ed. A. Maryniarczyk, Lublin 2011.

Smolana K., Polonia w Argentynie. Rys historyczny, [in:] Dzieje Polonii w Ameryce Eacińskiej, ed. M. Kula, Wrocław 1983.

Suchanow K., Gombrowicz. Ja, geniusz, vol. 2, Wołowiec 2017.

Supruniuk M. A., Polonica argentyńskie, „Archiwum Emigracji: studia, szkice, dokumenty" 1998, vol. 1.

Urbański E. S., Sylwetki polskie w Ameryce Łacińskiej w XIX-XX wieku, vol. 1, Stevens Point 1991.

Włodek J., Argentyna i emigracja. Ze szczególnym uwzględnieniem emigracji polskiej, Warszawa 1923.

Wójcik W., Polacy w Brazylii, Argentynie i Urugwaju w XIX i XX wieku, „Dzieje Najnowsze" 1972, vol. 2.

Yaben J. R., Biografías argentinas y sudamericanas, vol. 1, Buenos Aires 1938.

\section{WEBSITES}

Polonia Digital Library /Archiwum Polonijnej Biblioteki Cyfrowej (PBC): http://www. pbc.uw.edu.pl/view/divisions/Archiwum=5FCoronado.html (11.10.2020).

Official website of the Kozłów commune: Historia wsi Kozłów http://www.kozlow.pl/ art,175,historia-wsi-kozlow\&kalendarz=2017-08.html (11.10.2020).

Website of the Museum in Kraków: Rocznica powrotu Skarbów Wawelskich, https:// wawel.krakow.pl/rocznica-powrotu-skarbow-wawelskich (10.10.2020)

Warsaw obituaries: http://www.nekrologi-baza.pl/zmarly/684608 (2.10.2020).

Artillery Reserve Cadet School in Wlodzimierz Wolynski Rocznik Szkoty Podchorażych Rezerwy Artylerii, R.1934/1935, University Library in Poznań https://www. wbc.poznan.pl/dlibra/publication/109615/edition/120578/content?ref=struct (15.10.2020). 